\author{
УДК 93/94 ББК 63.3(2)41 DOI 10.25986/IRI.2019.75.1.0016 \\ П. В. Лукин \\ ИРИ РАН, Москва, Россия.lukinpavel@yandex.ru \\ СТАРЕЙШИНА ГОСТОМЫСЛ И ПЕРВЫЙ ДОЖ ПАОЛУЧЧО АНАФЕСТО:
РЕСПУБЛИКАНСКИЕ МИФЫ И ИХ СУДЬБЫ
}

Статья посвящена сравнительно-историческому анализу преданий о предыстории Новгородской и Венеџианской республик. Задачей автора является анализ представлений о легендарных «отџах-основателях» республик: Гостомысле, согласно легенде, первом новгородском посаднике, и Паолуччо Анафесто, согласно преданию, первом венеџианском доже. В отличие от Венеџии, в Новгороде миф о первом выборном правителе не получил развития, а представления о вольностях, которые были дарованы Новгороду русскими князьями-Рюриковичами, стали более популярными. Это обстоятельство, по-видимому, оказало влияние на эволюџию политической системы Новгородской республики и в итоге усилило в идеологическом отношении промосковскую партию.

Ключевые слова: Новгород, Венечия, республика, посадник, дож, средневековые предания, сравнительно-исторический анализ

Образ древнего правителя Новгорода Гостомысла постоянно эксплуатируется в около- и паранауке. Между тем собственно научных исследований, ему посвяџенных, немного. Древнейшие его упоминания датируются XV в. О посажении словенами «старейшины» Гостомысла говорится в сообшении, читаюшемся в летописях новгородскософийской группы (Новгородская IV, Софийская I и Новгородская Карамзинская 1-й выборки) в связи с сюжетом об их расселении: «Словене же, пришедше съ Дуная, съдоша около озера Ильмеря, и прозвашася своимъ именемъ, и здђлаша градъ и нарекоша и Новгородъ, и посадиша и старђшину Гостомысла... „». Также Гостомысл фигурирует в списке новгородских посадников: «А се посадниџђ новгородчьскыи: пръвыи Гостомыслъ...»

Дальнейшую разработку предание о Гостомысле получило уже после падения новгородской независимости и не в новгородской книжности. В начале XVI в. в «Послании о Мономаховом венџе», которое приписывается киевскому митрополиту Спиридону, Гостомысл преврашается в «воеводу новгородского» ${ }^{4}$. Перед смертью он созывает неких «владалџев» и дает им поручение призвать из Прусской земли князя, происходяшего от римского императора Августа. Таковым оказывается Рюрик 5 . Примерно такой же текст читается и в известном «Сказании о князьях владимирских ${ }^{6}$. Отсюда предание попадает в Воскресенскую летопись (см. об этом: [Лурье, с. 69]) ${ }^{7}$.

Гостомысл в дальнейшем появляется в русских и украинских памятниках XVII в. В «Сказании о Словене и Русе» о Гостомысле рассказывается в основном по «Сказанию о князьях владимирских», которое было одним из главных источников этого сочинения, но сам Гостомысл оказывается уже «старейшим князем» или «старейшинойкнязем» (а мифический Словен - соответственно, его сыном). ${ }^{8}$ В таком популярном в XVII-XVIII в. обзоре истории восточнославянских земель, как Киевский синопсис 1674 г., Гостомысл, «нарочит и разумен муж», выступает в роли избранного «россами» князя и иниџиатора призвания варягов, а княгиня Ольга оказывается его правнучкой9.

1 Сердечно благодарю Елену Аветову, А. А. Адашинскую и Я. А. Пенькову за содействие и возможность ознакомиться с труднодоступной в Москве литературой; А. М. Введенского и Е. Л. Конявскую за консультаџии.

2 ПСРЛ. М., 2000. Т. IV. Ч. 1. С. 3; М., 2000. Т. VI. Вып. 1; СПб., 2002. T. XLII. С. 22. В нашей монографии указание на упоминание Гостомысла в Софийской I летописи, по недосмотру, отсутствует (ср.: [Лукин, 2018, c. 66]). Пользуясь случаем, исправляем эту оплошность. Это известие содержится также в летописях, восходяших к так называемому «Краткому новгородскому летописцу» (далее: КНЛ ), см. соответственно Новгородскую Большаковскую летопись и Летописец епископа Павла: Конявская Е. Л. Новгородская летопись XVI в. из собрания Т. Ф. Большакова / / НИС. СПб., 2005. Вып. 10 (20). с. 348; Бобров А. Г. Летописание Великого Новгорода второй половины XV в. // ТОДРЛ. СПб., 2003. T. LIII. с. 109). Взаимоотношения между летописями новгородско-софийской группы и КНЛ до сих пор определенно не выяснены; в любом случае, КНЛ возник в Новгороде и не позднее первой четверти XV в. (см.: Конявская, 2010; Введенский, 2018). То, что известие о Гостомысле фигурирует в КНА, свидетельствует об определенной актуальности этого персонажа в Новгороде, по крайней мере, уже в первой половине XV в., поскольку, как было убедительно показано Е. $\lambda$. Конявской, новгородский составитель КН $\mathcal{\lambda}$ отбирал материал из своего источника сознательно и џеленаправленно (Конявская, 2010, с. 48-49). Последуюшие же летописџы, использовавшие КНЛ, также сохраняли это известие.

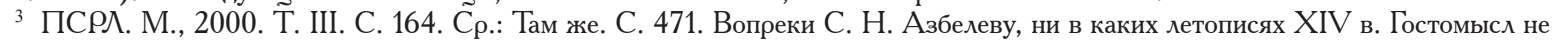
упоминается (ср.: [Азбелев, 2007, с. 64-65; Азбелев, 2017, с. 42]).

${ }_{4}^{4}$ Вопрос об авторстве Спиридона спорен (см.: [Ульяновский, с. 228-233; Алексеев, с. 5-9]).

5 Дмитриева Р. П. Сказание о князьях владимирских. М.; ᄉ., 1955. С. 162.

6 Там же. С. 175.

Любопытно, что Гостомысл «выпал» из Степенной книги, составитель которой использовал в соответствующем фрагменте легенды Никоновской и Воскресенской летописей (ПСРЛ. СПб., 1908. Т. ХХІ, 1-я половина. С. 60), хотя в обеих он фигурировал (ПСРЛ. СПб., 1856. Т. VII. С. 268; СПб., 1862. Т. IX. С. 3). А. С. Усачев справедливо замечает, что это связано с тенденџией памятника - опускать «описания действий князей не-

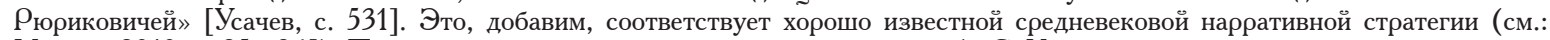
[Лукин, 2010, с. 85-86]). Попутно исправим одну неточность, допушенную А. С. Усачевым: «владальцев», правивших якобы вместе с ним Новгородом, было как минимум двое.

8 Изборник славянских и русских сочинений и статей, внесённых в хронографы русской редакџии / собр. и изд. А. Попов. М., 1869. С. 446-447.

9 Мечта о русском единстве. Киевский синопсис 1674 г. / Предисловие и подготовка текста О. Я. Сапожникова и И. Ю. Сапожниковой. М., 2006. С. 68, 73. О популярности Синопсиса, многократно издававшегося вплоть до начала XIX в., см.: [Формозов, с. 10-24]. 
Полного развития предание о Гостомысле достигает в «Истории российской» В. Н. Татиџева. Именно у Татищева Гостомысл оказывается, наконеџ, окончательно вписанным в династический контекст, становясь дедом основателя династии Рюрика, княгини Ольги, а заодно и еше одного легендарного новгородџа - Вадима Храброго, убитого, согласно Никоновской летописи, ююриком $^{10}$.

Любопытна эволюџия представлений В. Н. Татиџева о Гостомысле. В первой редакџии его труда сообшается со ссылкой на «Несторово сказание», что это был «князь, избранный от народа словенского, пришедших из Вандалии», по завету которого был, в свою очередь, избран Рюрик «от варяг руссов, по обстоятельствам королевич финской». Там же Гостомысл выступает в роли деда Ольги. Умер он якобы в 861 г. - перед призванием варягов ${ }^{11}$. В примечании, однако, историк полемизирует с собственным текстом. Так, он пишет, что у «словян» был «древний обычай князей не по выбору, но по наследию возводить», и, естественно, Гостомысл «был бы наследственной» - вот только «прежних владетелей наследия, ни завесчания не осталось». Высказывает В. Н. Татищев и предположение о том, что у Гостомысла «мужескаго наследия не было» ${ }^{12}$.

Окончательное оформление легенда о Гостомысле получает в известной по второй редакџии труда В. Н. Татищева так называемой Иоакимовской летописи (относительно ее происхождения и авторства идут дискуссии, см.: [Толочко, c. 196-245]) и примечаниях к ней самого историка. В Иоакимовской летописи рассказывается о вешем сне Гостомысла о древе, выросшем из чрева его средней дочери Умилы, что должно было символизировать происхождение от него династии русских князей, и прямо говорится о происхождении Ольги «от рода Гостомыслова» ${ }^{13}$. В примечаниях

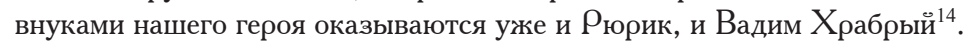

Из этого краткого обзора становится очевидным, что в древнерусской книжности имелось два Гостомысла: ранний, новгородский, и поздний, династический ${ }^{15}$. В историографии и, шире, в исторической мысли они, тем не менее, постоянно смешивались.

Ученых обычно привлекала проблема историчности Гостомысла. И здесь дурную службу ему сыграла поздняя, династическая, легенда. Конечно, находились и находятся оптимисты, готовые в нееповерить (см., например: [Азбелев, 2007, с. 65-77]), но все же ее откровенно ангажированный характер, сказочные детали ${ }^{16}$, да и, мягко говоря, сомнительность главного «источника», Иоакимовской летописи ${ }^{17}$, вызывали у большинства историков обоснованный скепсис. Отношение к Иоакимовской летописи в частности и к династическим легендам вообще распространилось и на новгородскогоГостомысла. Какправило, егофигурасчитаетсязаимствованнойизустныхпреданий,причемпозднейших, и /или каких-то внелетописных источников, тоже поздних (см. подробнее: [Гимон, с. 612-614; Лукин, 2018, с. 66-69]).

९ядом исследователей были высказаны, однако, иные оџенки. Так, А. А. Шахматов относил известие о Гостомысле - в ряду других ранних известий летописей новгородско-софийской группы к древнему новгородскому своду XI в. [Шахматов, с. 213 (§ 160№)]. Х. Ловмяньский отверг гипотезу о «консерваџии» устной традиџии «в столь аморфном и малоинтересном для слушателей контексте, без генеалогических связей с позднейшими новгородскими боярами» (историк, впрочем, считал, что упоминания о Гостомысле восходят к древнему нелетописному источнику - раннему списку посадников) [Łowmiański, s. 458]. Не так давно А. А. Гиппиу высказался в пользу появления «новгородского» Гостомысла в начальном летописании, но связал его не с древним новгородским сводом, а с реконструируемым им сводом Изяслава Ярославича 1060-х годов, составитель которого, по мнению исследователя, должен был хорошо знать новгородские реалии. Ученый отмечает в связи с этим, что «[б]ытуюшее мнение о позднем происхождении этой фразы не объясняет присутствия имени Гостомысла (несомненно, аутентичного и неизвестного из других древнерусских источников) в списке новгородских посадников» [Гиппиус, с. 48].

Итак, новгородский Гостомысл не связан с каким-либо фольклорным контекстом (он появляется постепенно у Гостомысла династического); исчезновение его из «мейнстримных» летописных текстов достаточно легко объясняется и имеет параллели в позднем летописании; наконеџ, его имя, безусловно аутентично для периода, к которому он отнесен в общем источнике летописей новгородско-софийской группы, и надежно подтверждено: похожие имена (с формантом «Гост - ) зафиксированы и на Руси (в том числе в берестяных грамотах ${ }^{18}$ ), и у западных славян; Гостомыслом звали и известного ободритского «короля» [Schlimpert, S. 23], о котором пойдет речь ниже.

Нами уже отмечалось то обстоятельство, что новгородский Гостомысл, если он и существовал

${ }^{10}$ ПСРЛ. Т. IX. С. 9.

${ }_{11}$ Татищев В. Н. Собрание сочинений. М., 1995. Т. IV. История российская. Ч. 2. С. 102, 112

12 Там же. С. 394.

13 Татищев В. Н. Собрание сочинений. М., 1994. Т. І. История российская. Ч. 1. С. 110-111.

14 Там же. С. 116, 117.

${ }_{15}$ На это ранее справедливо указывал В. Я. Петрухин [Петрухин].

16 Помимо сказанного выше, достаточно отметить, что, согласно Иоакимовской летописи, княгиня Ольга изначально «Прекраса нариџашеся», а приведший ее к Игорю Олег «преименова ю и нарече во свое имя Ольга» (!) (Татищев B. H. Собрание сочинений. Т. І. С. 111).

17 Подтверждение в Иоакимовской летописи выдвинутых ранее В. Н. Татиџевым гипотез о первых русских правителях (в том числе о Гостомысле и его родственных связях) заставляет с большой серьезностью отнестись к выдвигавшемуся предположению о том, что Татиџев и был автором этой летописи или, во всяком случае, приложил к ней руку (см.: [Толочко, с. 225-232]; вопреки А. П. Толочко, Умила у Татиџева - не старшая, а средняя дочь Гостомысла, ее сын - Рюрик, а сын старшей дочери - Вадим).

18 Зализняк А. А. Древненовгородский диалект. М., 2004. С. 240-241 (№ 527, 30-60-е годы XI в.); 300-301 (№ 9, 2-я пол. XII в.). Имеются в Новгородской земле и топонимы, происходяџие от антропонимов с препозитивным «Гост-» [Васильев, c. 167-168]. 
(в чем также, разумеется, нет полной уверенности), вряд ли мог быть как «старейшиной» Новгорода, так и его посадником [Лукин, 2018, с. 68-69]. Уже давно предпринимались попытки связать новгородского Гостомысла с упомянутым одноименным правителем ободритов. Даже тот факт, что ободритский Гостомысл погиб в войне с восточнофранкским королем Һюдовиком II Немеџким в 844 г., не помешал убежденному зашитнику исторической достоверности как новгородского, так и династического Гостомысла С. Н. Азбелеву утверждать, что западнославянский правитель выжил и бежал к берегам Ильменя. Ученый ссылается при этом на Ксантенские анналы, в которых - в отличие якобы от тенденџиозных, по его мнению, Фульдских анналов - «лишь глухо упомянуто», что ободритский Гостомысл «погиб или исчез (interiit)» [Азбелев, 2007, с. 67-68]. Однако латинский глагол intereo и означает 'погибать', а 'исчезать' лишь в смысле 'кончаться, угасать' (например, об огне) ${ }^{19}$. Так что ничего глухого в Ксантенских анналах нет, и с мечтой о спасении «короля» Гостомысла приходится расстаться ${ }^{20}$. Не так давно А. А. Горский предположил, что появление на Руси предания о Гостомысле основано на исторической памяти новгородџев и обусловлено контактами новгородских словен с ободритами [Горский, с. 88-89]. Этого нельзя исключать, и связи Новгорода с западными славянами действительно имели место (хотя в историографии, особенно в так называемой антинорманистской, имеется тенденџия к их непомерному преувеличению). Но не менее вероятно, что «исторический Гостомысл» мог быть таким же «племенным» правителем словен, какими были древлянский Мал или вятичский Ходота (существование последнего, упомянутого Владимиром Мономахом в своем «Поучении», абсолютно бесспорно). Так или иначе, очень вероятно, что новгородское предание о Гостомысле отталкивалось от некоей реальности. Книжник, включивший это предание в протограф летописей новгородско-софийской группы, и его последователи, очевидно, видели в нем историю выборов и «посажения» самими словенами «старейшины» - по сути дела, первого «протореспубликанского» магистрата. Нельзя не усмотреть тут некий элемент формируюшейся легенды de origine rei publicae Nogardensis.

Перенесемся теперь с суровых берегов Балтики и Ильменя к Адриатическому морю. В древнейшей венеџианской хронике дьякона Джованни (начало XI в.) рассказывается о самостоятельном избрании в 10-е годы VIII в. венеџианџами первого дожа - Павликия (Паолуччо): «И вот во времена императора [Византии] Анастасия и Лиутпранда, короля лангобардов, все венеџианџы, собравшись вместе с патриархом [Градо] и епископами, совместно постановили, что отныне более почетно для них будет пребывать под властью дожей, чем трибунов. И после долгого обсуждения о том, кого из них выдвинуть на этот высокий пост, они, наконеџ, нашли опытнейшего и славнейшего мужа по имени Павликий и, дав ему клятву верности, поставили дожем у города Эраклеи» ${ }^{21}$. Впоследствии «первый дож» получил дату избрания - 697 г. (в хронике Андреа Дандоло середины XIV в. $)^{22}$ и фамилию - Анафесто ${ }^{23}$.

Помимо хроник, включая самые ранние, дож Паолуччо упоминается во всех четырех древнейших перечнях венеџианских дожей (трудно не увидеть тут поразительную близость с новгородскими источниками этого типа, что должно стать, как представляется, предметом отдельного исследования: вряд ли случаен тот факт, что подобные однотипные каталоги возникли в средневековых республиках). О Паолуччо там говорится очень кратко: «Дож Павликий правил 20 лет и 6 месяџев и 9 дней» ${ }^{24}$. Все эти перечни восходят к общему источнику, его датировка является спорным вопросом, как и датировка возможного источника сведений дьякона Джованни о древнейшем прошлом Венеџии - так называемых annales antiqui. Так или иначе, уже в самой ранней венеџианской исторической традиџии

19 Дворецкий И. Х. Латинско-русский словарь. М., 1986. С. 414.

20 «Hludowicus Obodritos defectionem molientes bello perdomuit occiso rege eorum Goztomuizli terramque illorum et populum sibi divinitus subiugatum per duces ordinavit» (Annales Fuldenses sive Annales regni Francorum orientalis / Rec. F. Kurze. Hannoverae, 1891 (Scriptores rerum Germanicarum in usum scholarum ex MGH recusi). S. 35); «Ibique unus ex regibus eorum interiit, Gestimus [sic!] nomine, reliqui vero fidem prebentes veniebant ad eum (к Людовику Немеџкому. - П. А.)» (Annales Xantenses et annales Vedastini / Rec. B. de Simson. Hannoverae; Lipsiae, 1909 (Scriptores rerum Germanicarum in usum scholarum ex MGH separatim editi). S. 14).

${ }_{21}$ «Temporibus nempe imperatoris Anastasii et Liuprandi Langobardorum regis, omnes Venetici, una cum patriarcha et episcopis convenientes, communi consilio determinaverunt, quod dehinc honorabilius esse sub ducibus quam sub tribunis manere. Cumque diu pertractarent quem illorum ad hanc dignitatem proveherent, tandem invenerunt peritissimum et illustrem virum, Paulitionem nomine, cui iusiurandi fidem dantes, eum apud Eraclianam civitatem ducem constituerunt» (Giovanni diacono. Istoria Veneticorum / Ed. e trad. di L. A. Berto. Bologna, 1999. II. 2. Р. 94; здесь и далее переводы с латинского языка и volgare наши. - П.Л.). Трибуны должностные лиџа в византийской Италии, подчиненные dux'y (герџогу, дожу) или magistro militum и управлявшие отдельными городами и крепостями, позднее это обозначение стало применяться к џелому слою местной знати; Эраклея (Гераклея) - до 742 г. главный город Венеџианской лагуны.

${ }_{22}$ Andrea Danduli, ducis Venetiarum. Chronica per extensum descripta / A cura di E. Pastorello. Bologna, 1938 (Rerum italicarum scriptores. T. XII. P. I). P. 105-106.

23 По-видимому, впервые фамилия Анафесто появляется также не ранее середины XIV в., древнейшее упоминание, возможно, содержится в так называемой хронике Энрико Дандоло, написанной на volgare: «Паолуччо по прозванию Анафесто был избран всей знатью и всеми другими жителями Эраклеи первым дожем, в указанном городе, который... потом стал называться Читтанова...» («Paolucio prenomado Anafesto universalmente da gli nobili et tuti altri habitanti in Erecliana fu electo primo Doxe nela dicta citade, la qual... fu et è da poi apelada Citanova ...» (Cronica di Venexia, detta di Enrico Dandolo: origini - 1362 / A cura di R. Pesce; presentazione di A. Caracciolo Aricò. Venezia, 2010. Р. 14)). В ранних источниках почти у всех первых дожей фамилий нет, см.: Le vite dei dogi di Marin Sanudo / A cura di G. Monticolo. Città di Castello, 1900 (Rerum italicarum scriptores Raccolta degli storici italiani dal cinquecento al millecinquecento. T. XXII. P. IV). Vol. I. P. 99, n. 2 (автор комментариев - Дж. Монтиколо).

${ }_{24}$ «aulicius dux ducavit annos XX et menses VI et dies VIIII» (Chronache veneziane antichissime / A cura di G. Monticolo. Roma, 1890. Vol. I. (Fonti per la storia d'Italia. Sec. X-XI). P. 177). 
фиксируются следуюшие опорные пункты: 1) переселение населения в лагуну в результате нашествия лангобардов; 2) самостоятельное формирование им администраџии (так называемых трибунов); 3) установление власти дожей и избрание первого из них - Паолуччо. Из этой схемы выросло впоследствии все раскидистое дерево венеџианского исторического мифа. В џелом эта схема фантастична или даже, как писал один из самых выдающихся спеџиалистов по истории ранней Венеџии, Роберто Чесси, представляет собой вымысел, ложь (menzogna) [Cessi, p. 161-162]. Тем не менее, как отмечает тот же исследователь, она опирается на реальные события и явления: факт лангобардского нашествия; наличие в зоне Венеџианской лагуны института трибунов; появление в какой-то момент дожей, перечень которых, начиная с определенного этапа, становится достоверным. Главное, что обходит эта схема и в чем она принџипиально не соответствует подлинной истории региона, - это замалчивание власти Византии над лагуной ${ }^{25}$. Двумя столетиями позднее легендарного Паолуччо датируется и возникновение проџедуры избрания дожа.

По убедительному предположению Р. Чесси, прототип «первого дожа» хронист обнаружил в имевшемся в его распоряжении пакте франкского императора Лотаря I 840 г. Там дважды упоминается некий dux $\rho_{a u l i t i o}$ (или Paulitius), осушествивший межевание граниџ города Гераклеи (Эраклеи, Читтанова, Civitas nova) вместе с magister militum Марџеллом или - в другом варианте - с жителями Читтановы (cum Civitatinis novis) при ᄉиутпранде, короле лангобардов в $712-744$ г. ${ }^{26}$ На основе тщательного анализа Р. Чесси приходит к выводу, что этим «Павликием» мог быть экзарх Равенны Павел, а само размежевание имело место в 20-е годы VII в. Иными словами, прообразом первого выборного дожа послужил назначенный из Византии чиновник, то есть реальная зависимость от Восточной Римской империи обернулась в базовом венеџианском мифе de origine своей противоположностью - независимым формированием ключевого республиканского института путем выборов на народном собрании. Причем автор хроники ничего не выдумывал: он вполне искренне думал, что в находившемся в его руках документе имелся в виду действительно выборный венеџианский дож, каковым он и был в его время. И «реконструировал» проџедуру его избрания в соответствии с современными ему порядками.

Очень вероятно, что примерно такого же происхождения был и «первый новгородский посадник» Гостомысл. Новгородские книжники, переписывавшие древние предания, вполне искренне видели в нем своего первого выборного правителя. Судьба «первого посадника» была, однако, куда более печальной, чем судьба «первого дожа». Предание о нем не получило дальнейшего и, можно даже сказать, должного развития. Почему не получило и почему «должного»?

В Новгороде предпочитали, как известно, выводить свою вольность от древних князей, что нашло проявление в целом ряде сентенџий летописџев еще XII в., таких, например, как: «Новъгород выложиша вси князи въ свободу: кдъ имъ любо, ту собъ князя поимают» 27 или «...издавна суть свобожени Новгородџи прадъды князь наших ${ }^{28}$. Наиболее выпукло эта конџепџия отразилась в известном предании о Ярославлих грамотах, на которых присягали Новгороду князья в XIII-XIV в. ${ }^{29}$ Чем бы они ни были, предание о них подразумевает два исходных пункта: вольность новгородџев, гарантированную документально; дарование этих гарантий князем. Именно эта схема стала системообразуюшей в новгородском мифе о вольности. Альтернативные же - о Гостомысле как о первом и независимом от каких-либо русских князей посаднике или о происхождении новгородџев не от обязанных

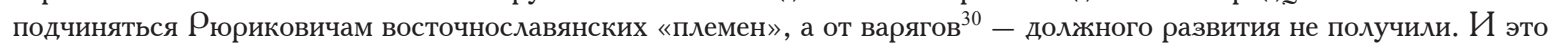
несмотря на то, что, как мы видели, на «рынке идей» подобные конџепџии имелись.

Все это не могло не внести свой вклад в готовность Новгорода признавать себя «отчиной» великих князей. Готовность, которая в психологическом плане мешала порвать связи с Москвой (хотя такие возможности имелись и на рубеже XIV $-\mathrm{XV}$ в., в период активной «восточной» политики великого князя Литовского Витовта, и в 70-е годы XV в. (см.: [von der Osten-Sacken, s. 16-32; Krupa, s. 298-300]) и сослужила службу промосковской партии в самом Новгороде. В этом контексте позиџия тех новгородџев, которые перед Шелонской битвой кричали: «За великого князя хотим по старинь, как было преже сего»31, вполне объяснима. Новгородской элите, в отличие от венеџианской, не удалось не только консолидироваться и ликвидировать инфраструктуру в виде народного собрания, где могли высказываться подобные взгляды, но и создать такую версию своего происхождения республиканских свобод и своего собственного, которая исключала бы зависимость от внешних сил. Гостомысл оказался невостребованным и роль его, к сожалению для историков республиканского пути развития русской государственности, осталась несыгранной.

\footnotetext{
${ }^{25}$ О власти Византии над Венеџией см., например: [Ravegnani, р. 5-13].

MGH Legum Sectio II. Capitularia regum francorum. T. II / Ed. A. Boretius, V. Krause. Hannoverae, 1897. № 233. S. 135.

${ }_{27}^{27}$ ПСРЛ. Т. III. C. 236.

28 ПСРЛ. М., 1997. Т. І. Стб. 362; Ср.: ПСРЛ. М., 1998. Т. ІІ. Стб. 561. См. об этом подробнее: [Фр с. 298-299; Лукин, 2018, с. 511-512].

29 Историю вопроса см.: [Петров, с. 63-87].

30 Идею о происхождении новгородџев «от рода варяжьска» (ПСРЛ. Т. ІІІ. С. 106) мы планируем рассмотреть отдельно также в компаративном контексте.

${ }^{31}$ ПСРЛ. М., 2004. Т. XXV. С. 284.
} 


\begin{abstract}
Литература
Азбелев С. Н. Устная история в памятниках Новгорода и Новгородской земли. СПб., 2007.

Азбелев С. Н. Гостомысл // Исторический формат. 2017. № 3-4. С. 41-66.

Алексеев А. И. «Спиридон рекомый, Савва глаголемый» (заметки о сочинениях киевского митрополита Спиридона) // Древняя Русь. Вопросы медиевистики. 2010. № 3 (41). С. 5-16.

Васильев В. А. Архаическая топонимия Новгородской земли (Древнеславянские деантропонимные образования). Великий Новгород, 2005.

Введенский А. М. О нижней граниџе создания общего протографа псковских летописей // Rossica Antiqua. СПб., 2018. № 16 (1). (в печати)

Гимон Т. В. События XI - начала XII вв. в новгородских летописях и перечнях // Древнейшие государства Восточной Европы. 2010. М., 2012. С. 584-703

Гиппиус $A . A$ К К реконструкџии древнейших этапов истории русского летописания // Древняя Русь и средневековая Европа: возникновение государств. Материалы конфер. М., 2012. С. 41-50.

Горский $A . A$. К вопросу о происхождении славянского населения Новгородской земли // От Древней Руси к новой России. Юбилейный сб., посвященный чл.-корр. РАН Я. Н. Щапову. М., 2005. С. 83-94.

Конявская E.Л. Краткий новгородский летописеџ и его место в новгородском летописании // Древняя Русь. Вопросы медиевистики. 2010. № 1 (39). С. 40-52.
\end{abstract}

Аукин П. В. Восточнославянские «племена» и их князья: конструирование истории в Древней Руси // Славяне и их соседи. $\mathrm{XXV}$ конфер. памяти В. Д. Королюка. Предания и мифы о происхождении власти эпохи Средневековья и раннего Нового времени. М., 2010. С. 83-89.

Аукин П. В. Новгородское вече. 2-е изд., перераб. и доп. М., 2018.

Лурье Я. С. Древняя Россия и Россия новая (Избранное). СПб., 1997.

Петров А. В. От язычества к Святой Руси. Новгородские усобиџы (к изучению древнерусского вечевого уклада). СПб., 2003.

Петрухин В. Я. Гостомысл: к истории книжного персонажа // Славяноведение. 1999. № 2. С. 20-23.

Толочко А. П. «История российская» Василия Татиџева: источники и известия. М.; Киев, 2005.

Ульяновский В. И. Митрополит киевский Спиридон: явные и скрытые повествования о себе в сочинениях 1475-1503 гг. // ТОДРЛ. СПб., 2006. Т. 57. С. 209-233.

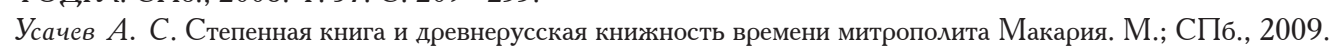

срлоря Б. Н. Новгород и князья в XII в. // Великий Новгород и Средневековая Русь: Сб. ст.: К 80-летию академика В. ᄉ. Янина. М., 2009. С. 295-299.

Формозов $A . A$. Классики русской литературы и историческая наука. М., 2012.

Шахматов А. А. Разыскания о древнейших русских летописных сводах. СПб., 1908.

Cessi R. Paulicius dux // Cessi R. Le origini del ducato veneziano. Napoli, 1951. P. 158-179.

Krupa K. Polityczne związki Giedyminowiczów z Nowogrodem Wielkim w latach 1430-1471 // Przegląd historyczny. 1993. T. 84. Z. 3. S. 289-306.

Łowmiański H. Gostomysł posadnik nowogrodzki w końcu X wieku / / Łowmiański H. Studia nad dziejami Słowiańszczyzny, Polski i Rusi w wiekach średnich. Poznań, 1986 (1-е изд. - 1965). S. 457-463.

von der Osten-Sacken P. Livländisch-Russische Beziehungen während der Regierungszeit der Grossfürsten Witowt von Litauen (1392-1430). Riga, 1908.

Ravegnani G. Venezia bizantina // Porphyra. 2008. A. V. № 11. Р. 5-13. URL: http://www.porphyra.it/Porphyra11.pdf (дата обрашения: 29.12.2018).

Schlimpert G. Slawische Personennamen in mittelalterlichen Quellen Deutschlands. Berlin, 1964 (Deutsch-Slawische Forschungen zur Namenkunde und Siedlungsgeschichte. № 17).

\author{
Pavel V. Lukin
}

The Institute of Russian History of the Russian Academy of Sciences, Moscow, Russia

\title{
ELDER GOSTOMYSL AND THE FIRST DOGE PAOLO LUCIO ANAFESTO: REPUBLICAN MYTHS AND THEIR FATES
}

The article is devoted to the comparative analysis of the legends on the origins of Novgorod and Venetian republics. The author focuses on the images of the legendary 'founding fathers': Gostomysl, the first posadnik (burgomaster) of Novgorod, and Paolo Lucio Anafesto, the first Doge of Venice. Unlike in Venice, in Novgorod a myth on the first elected ruler did not develop, while ideas of the liberties granted by the princes-Rurikids became much more popular. It may have influenced political evolution of Novgorod and eventually strengthened ideologically the pro-Moscow party.

Keywords: Novgorod, Venice, republic, posadnik, Doge, medieval legends, comparative analysis 